\title{
Earnings Management and Audit Quality: Evidence from Malaysia
}

Nor Balkish Zakaria, Hanis Athirah Zulkefeli, Rahayu Abdul Rahman

To Link this Article: http://dx.doi.org/10.6007/IJARAFMS/v12-i1/11621 DOI:10.6007/IJARAFMS /v12-i1/11621

Received: 19 November 2021, Revised: 23 December 2021, Accepted: 12 January 2022

Published Online: 24 January 2022

In-Text Citation: (Zakaria et al., 2022)

To Cite this Article: Zakaria, N. B., Zulkefeli, H. A., \& Rahman, R. A. (2022). Earnings Management and Audit Quality: Evidence from Malaysia. International Journal of Academic Research in Accounting Finance and Management Sciences, 12(1), 98-118.

Copyright: @ 2022 The Author(s)

Published by Human Resource Management Academic Research Society (www.hrmars.com)

This article is published under the Creative Commons Attribution (CC BY 4.0) license. Anyone may reproduce, distribute, translate and create derivative works of this article (for both commercial and non-commercial purposes), subject to full attribution to the original publication and authors. The full terms of this license may be seen at: http://creativecommons.org/licences/by/4.0/legalcode

Vol. 12, No. 1, 2022, Pg. 98 - 118

Full Terms \& Conditions of access and use can be found at http://hrmars.com/index.php/pages/detail/publication-ethics 


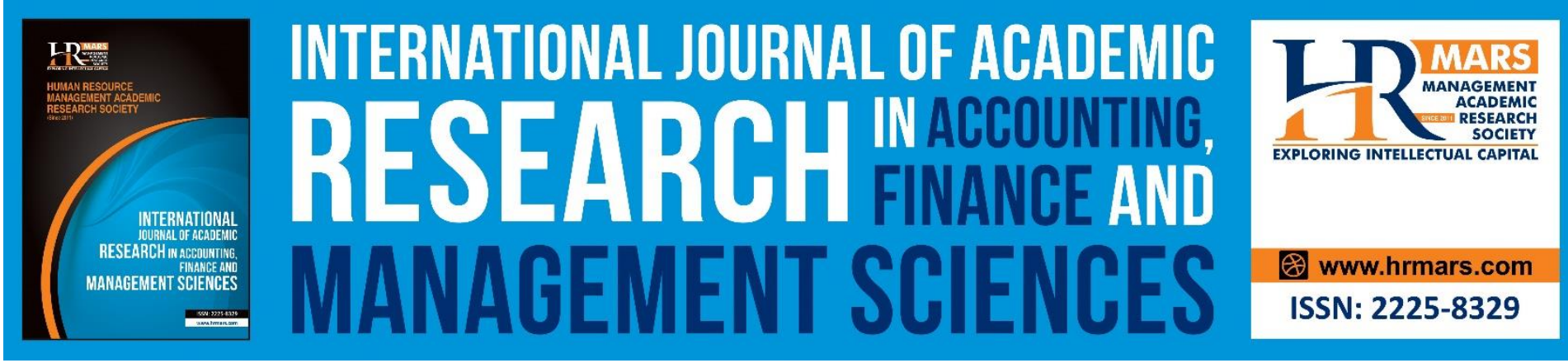

\title{
Earnings Management and Audit Quality: Evidence from Malaysia
}

\section{Nor Balkish Zakariaa, Hanis Athirah Zulkefelia, Rahayu Abdul Rahman ${ }^{b}$}

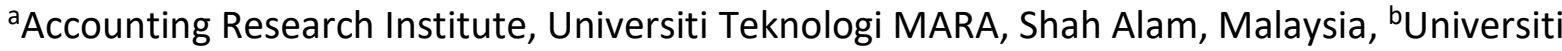
Teknologi MARA, Tapah, Perak, Malaysia

\begin{abstract}
This paper aims at investigating the relationship of audit market share, industry specialisation and Big 4 towards earnings management. The research posits that audit market share and industry specialisation constrains earnings management. In addition, it hypothesized a positive relationship between Big 4 and earnings management. The data was gathered from Data Stream, Thomson Reuters to test the research hypotheses. Out of 1488 companies-years observation between 2015 to 2018, the results indicate that there is no significant difference between audit market share and industry specialist auditors in constraining earnings management. In addition, findings support that Big 4 was significantly higher when specialists conducted the audit. The results provide empirical evidence consistent with the hypothesis that auditor with big size improves audit quality.
\end{abstract}

Keywords: Earnings Management, Audit Quality, Audit Specialisation

\section{Introduction}

High quality financial reporting will assist users to make right decisions. The right decision then will lead to optimum allocation of resources that plays a significant role in contribution to a country's economic success. In financial reporting, financial performance is mainly evaluated based on the information gathered from earnings and its components. Tariverdi (2007) documented that no doubt the objective of accounting is to define earnings, that is, the rest of the objectives of accounting are determined in the framework which defines earnings, since earnings is the return from investment.

Earnings management is the choice by a manager of accounting policies so as to achieve some specific objective (Scott, 1997). According to Siregar and Utama (2008), there are two types of earnings management; efficient earnings management that expands earnings in formativeness in communicating private information and opportunistic earnings management which reports earnings opportunistically to maximize companies' utility. Healy and Wahlen (1999) revealed that earnings management happens when managers use judgment in financial reporting and in structuring transactions to alter financial reports to either mislead certain stakeholders about the underlying economic performance of the company, or to influence contractual outcomes that depend on reported accounting numbers. 
MANAGEMENT SCIENCES

Vol. 12 , No. 1, 2022, E-ISSN: 2225-8329 (c 2022 HRMARS

The demand for auditing has risen due to conflicts between shareholders, as principals, and managers as the agents which lead to the agency problems (Jensen and Meckling, 1976). Therefore, auditors may act as the external governance mechanisms that reduce agency problems by constraining earnings management practices. The effectiveness of auditing depends on an auditor's ability to constrain manager in earning manipulation, since auditors with higher quality are more likely to discover inappropriate accounting practice (Becker et al., 1998). Thus, the important strategic decision for an audit company is industry specialisation which will impact on the audit pricing, audit quality and financial reporting quality that lead primary interest regulators and financial statement users (Cahan et al., 2008).

The goal for large audit companies in the United States is to be said is auditor specialisation that is increasing its importance in some (Hogan and Jeter, 1999). This implies that the concerned audit companies have perceived a benefit from specialisation whether increased profit, market share, audit quality or merely the maintenance of market share in competitive environments. The predominance of audit market share by the Big 4 accounting companies appears to be a common feature for countries such as the United States (Rhode, Whitsell and Kelsey, 1974) and Australia (Craswell and Taylor, 1991). They are making great efforts to seek high growth and competitive advantages in the international market. Despite the many studies carried out on this topic, there is still little research being carried out in the Malaysian context. A study conducted by Takiah and Aini (2000) showed that there is no industry specialisation for the auditor in the country. Also, research done by Mansor and Maruhun (2013) concluded that even a merger of Big 5 to Big 4 results increased their market prices, but still a specialisation by industry among auditors does not exist in Malaysia.

Hence this study aims to:

- Examine the relationship between audit market share and earnings management.

- Examine the relationship between industry specialization and earnings management.

- Examine the relationship between Big 4 and earnings management.

The remainder of this paper is organized as follows. The first section discusses literature review and the hypotheses developed for assessment and testing. The second section addresses the data collection, sample selection and the design of the experiment. The fourth section describes the empirical results and discussion. The conclusion and recommendations for future research are presented in the last section.

\section{Prior Studies and Hypotheses Development Agency Theory}

Agency theory attempts to designate the relationship between the principal and the agent (Duru and Tsitinidis, 2013). Hence, agency theory is viewed through the angle of a global agency. Jensen and Meckling (1976) defined agency theory as the relationship between an agent referring to the management, and principal which is an owner of the company. In similar vein, an agency relationship arises when the principal empowers an agent to act on behalf of their interest (McGuire, 1988). Jensen and Meckling (1976) explained more on agency theory where it is an explanation on how the public corporation could exist, given the assumption that managers are self-interested, and the context in which those managers do not bear the full wealth effects of their decision. 
MANAGEMENT SCIENCES

Vol. 12 , No. 1, 2022, E-ISSN: 2225-8329 @ 2022 HRMARS

By looking at these definitions, agency theory is based on the bargaining process between two parties over outcome (McGuire, 1988). This process will lead to agency problem between principal and agent. Brennan (1995) stated that conflict of interest may give and affect to the company's share prices. Accordingly, Davidson, Jiraporn, Kim and Nemec (2004) stated that agency problems arise when managers do not operate the corporation for the best interests of shareholders. As a result, managers do not always act to maximize shareholders' return on investment. Therefore, it will raise a conflict of interest between managers and shareholders because both parties have different goals.

\section{Earnings Management}

Schipper (1989) defined earnings management as the purposeful intervention by management in the earnings determination process, usually to satisfy selfish objectives. It often involves window-dressing financial statements, especially the bottom line earnings number. Meanwhile Chih, Shen and Kang (2008) defined earnings management as the application of insider's discretion in financial reporting in order to overstate the true amount of earnings and understate any actual earning losses or decrease. Similarly, Tangjitprom (2013) referred earnings management as the efforts of managers or executives in manipulating the earning figures in financial reporting. Healy and Wahlen (1999) pointed out that earnings management occurs when managers use judgment in financial reporting in structuring transactions to alter financial reports to either mislead some stakeholders about the underlying economic performance of the company or to influence contractual outcomes that depend on reported accounting numbers.

The financial scandals like Enron and Worldcom have generated a public perception that earnings management is utilized opportunistically by company managers for their own private benefits rather than for the benefits of the stockholders. Several studies examined whether managers with incentives to manipulate earnings due to the nature of their compensation contracts actually manage earnings. Healy (1985) documented the evidence consistent with the findings that executives manage earnings downwards when their bonuses are at their maximum. Dechow and Sloan (1991) found that CEOs tend to decrease the spending on research and development in their final employment years, possibly to increase reported earnings. Reinforcing this negative public perception on earnings management is the fact that regulators have lately devised a number of measures for the purpose of combating earnings management.

Saleh, Iskandar, and Rahmat (2003) provided evidence that listed companies in Malaysia may practice earnings management by examining factors that may influence the accounting accrual choices by Malaysian managers within the socioeconomic and institutional environment of Malaysia. Due to the financial crisis in 1997, there was a rapid withdrawal of private capital by foreign investors and rapid expansion of credit to companies operating in Malaysia (Sulaiman et al., 2000). Hence, the corporate sector became more leveraged and heavily dependent on commercial bank financing after 1997. Financial difficulties faced by companies might have become the primary factor that drove managers to improve upon their performance through earnings management.

\section{Audit Quality}

Audit quality is the heart of auditing. Lacking of audit quality is the leading cause of an audit failure. In the wake of accounting scandals and audit failures (e.g. Enron and WorldCom in the US at the beginning of the 21st century and the UK recent financial downturn), 
MANAGEMENT SCIENCES

Vol. 12, No. 1, 2022, E-ISSN: 2225-8329 @ 2022 HRMARS

regulators and standard setters have struggled to promote audit quality, for example the UK's Financial Reporting Council and the International Auditing and Assurance Standards Board (IAASB). Even though there have been attempts to promote audit quality, what audit quality is remains open to question.

DeAngelo (1981) defines audit quality as the market-assessed joint probability that a given auditor will both (a) discover a breach in the client's accounting system and (b) report the breach. Knechel, Krishnan, Pevzner, Shefchik and Velury (2013) wrote that a good audit is where there is implementation of a well-designed audit process by properly trained and motivated auditors who understand the essential uncertainty of the audit and appropriately adjust to the unique conditions of the client. Various empirical studies have proposed various definitions of audit quality. Given the disagreement among academics and regulators on the definition of audit quality, a consensus on the definition of a simple concept such as audit quality has not been achieved.

The Financial Reporting Council in the United of Kingdom (FRC) was the first regulator in the world to issue official documents relating audit quality from 2006 onwards. In its discussion paper in 2006 called "Promoting Audit Quality", it said that "there is no single agreed definition of audit quality that can be used as a 'standard' against which actual performance can be assessed" (FRC, 2006). There is no perfect definition could be used as a guideline to evaluate real audit quality. This may be because the stakeholders of audit seem to have different perceptions on audit quality.

\section{Audit Market Share and Earnings Management}

DeAngelo (1981) stated that Big 6 audit companies are the largest audit companies in US market, larger size audit companies often have higher the expected audit quality, less opportunistic behaviors of auditors are found. They are more likely to report error, fraud and irregularities and less likely to accept questionable accounting estimates. Becker et al. (1998) experimentally support the positive relationship between audit company size and audit quality, and they also examine the effect of audit quality to earnings management. The results indicate that the companies audited by non-Big 6 audit companies have higher discretionary accruals than the companies audited by Big 6 .

Choi, Kim, and Zang (2010) had done researched for Taiwanese companies have found that Big 5 auditors are related to lower abnormal accruals. Inaam et al. (2012) has conducted a research in Tunisian that there are negative and significant relationship between Big 4 and the earnings management measured by discretionary accruals. On the whole, most literatures support the negative relationship between audit company size and earnings management. However, some Chinese scholars also find positive relationship or no relationship between them given the specific institutional features in China. Feng and Fei (2002) (2002) claimed that international Big 4 in China face moral hazard problems, which negatively impact their ability to control earnings management. Basically, the relationship between audit company size and earnings management is still a complex empirical question in China. The varied result therefore, set off for the first hypothesis as follow:

H1 There is a significant relationship between audit market share and earnings management.

\section{Industry Specialisation and Earnings Management}

Bonner and Lewis (1990) thought that audit companies with industry expertise have more professional knowledge and skills, which help them to find accounting misstatements 
MANAGEMENT SCIENCES

Vol. 12, No. 1, 2022, E-ISSN: 2225-8329 @ 2022 HRMARS

easily and constrain false misrepresentation of accounting surplus of conduct. Meanwhile, Keefe, King and Gaver (1994) found that compared with non-specialist auditors, specialist auditors comply with accounting and auditing standards more strictly, and legal proceedings received are significantly less. The study results by Sun and Liu (2013) showed that assigning an auditor industry specialization in a particular client industry, will positively benefit the client because they can keep the quality of company earning better, which at last will increase the audit quality.

An auditor's knowledge about a client or an industry can reduce the probability of audit failure and reduce fraud because the auditor tends to have better evidence-gathering capability and be able to make sound professional judgements. Moreover, Mayangsari and Sudiboyo (2006) stated that the auditor's industry specialization give significant influence on the reliability of the company's audited financial statements allegedly as a result of highquality audits. However, Balsam et al. (2003) find a negative relation between auditor industry specialization and the client's absolute discretionary accruals. Thus, the contradicting literatures motivate for the development of second hypothesis as follow:

H2 There is a significant relationship between industry specialization and earnings management.

\section{Auditor Quality and Earnings Management}

Auditor is an important control mechanism that reduces information asymmetries between management and investors by providing independent verification to the financial reports prepared by the companies (DeAngelo, 1981, Becker et al., 1998). Further, auditing standards also emphasize the significance roles of external auditor as the communication device between management and external stakeholders. Past literatures found positive connection between auditor size and audit quality. The large audit company is predicted to deliver high audit quality as the financial statements for clients of Big audit company can be more faithfully representative, in terms of neutrality, completeness, and free from error, than clients of non-Big audit company (Lee and Lee, 2013).

Also, Big Audit Company has more incentives to detect any possibility of audit failure and positively contribute to credibility offered by auditor because they want to maintain their honor reputation, thus guarantees high quality of audit (Lee and Lee, 2013; Zakaria and Daud, 2013). This is supported by Lee and Lee (2013) and Bauwhede, Willekens and Gaeremynck (2003) that argued large auditors (Big 6) are more competent and provide higher quality service compared to smaller auditors (non-Big 6) because large auditors lose more when audit failure occurs, so they have harder inspirations to detect the likelihood of audit failure in order to maintain their good reputation.

A number of studies found that Big auditor has negative relationship with earnings management. Krishnan (2003) implied that auditor specialists in certain industry can moderate earnings management as they have high audit quality in terms of expertise, resources and incentives to mitigate opportunistic earnings management. Similarly, Chia, Lapsley and Lee (2007) documented that Big 6 audit companies significantly reduce earnings management activities in service-oriented public listed companies in Singapore during Asian financial crisis.

Conversely, Bauwhede (2003) do not found any proof of audit-quality differentiation between Big 6 audit company and non-Big 6 audit company through income-increasing earning manipulation, not even in the public listed companies. Furthermore, there is no significant difference of discretionary accruals between companies that appoint Big 6 and 
MANAGEMENT SCIENCES

Vol. 12, No. 1, 2022, E-ISSN: 2225-8329 @ 2022 HRMARS

non-Big 6 as their auditors in Korea (Jeong and Rho, 2004). Hence, this study proposed the third hypothesis as follows:

$\mathrm{H} 3$ There is a significant relationship between Big 4 and earnings management.

\section{Research Methodology}

\section{Theoretical Framework}

This paper aims to investigate whether the occurrence of earnings management is associated with audit market share, industry specialisation and Big 4 in 372 Malaysian Public Listed Companies. It is controlled by three control variables which are company size, performance, and leverage. These variables are chosen based on previous studies that have proven the variables to influence earnings management. Hence, the framework is drawn based on prior literature that were collected pertaining to the relationship between the audit market share, industry specialisation and Big 4 with earnings management that is represented in Figure 1.

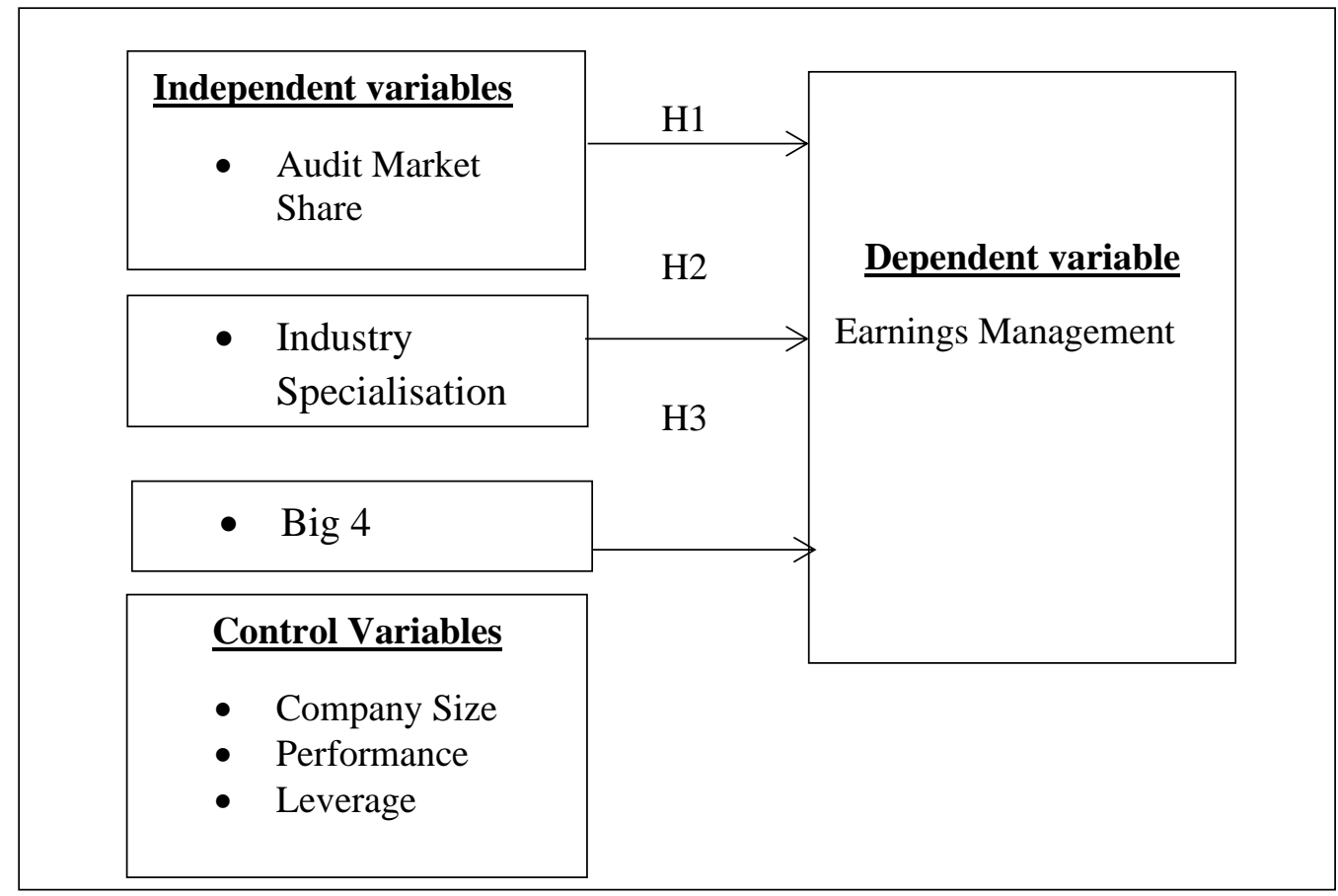

Figure 1: Theoretical Framework

\section{Sample of Study}

The population of the study is 922 public listed companies taken from the main board and ACE market in the Bursa Malaysia Board that consists of nine types of companies as at $1^{\text {st }}$ Jan 2015. However, the population frame excludes finance and bank institutions due to the differences of unique characteristics and compliance and regulatory environments. 
MANAGEMENT SCIENCES

Vol. 12 , No. 1, 2022, E-ISSN: 2225-8329 (c 2022 HRMARS

Table 1: Sample Selection Process

\begin{tabular}{|l|l|}
\hline & Companies \\
\hline Main board companies & 814 \\
\hline ACE market companies & 108 \\
\hline Total Population as at 31 November 2015 & $\mathbf{9 2 2}$ \\
\hline (-) Insufficient data and missing observation & 491 \\
\hline (-) Financial institution and banking & 59 \\
\hline TOTAL SAMPLE & $\mathbf{3 7 2}$ \\
\hline
\end{tabular}

Companies-Year Observation (372x4 years (2015-2018)) 1488

Based on Table 1, the samples selected of this study were taken from nine industries by employing a random sampling approach in the Main Board. The nine industries consist of construction and material, electronic and electrical equipment, general industrials, industrial engineering, household goods and home construction, industrial metal and mining, industrial transportation, software and computer services, and consumer product companies. However, 59 companies of the total sample had to be excluded due to financial institution and banking industry that have different regulation compared to non-financial companies retrieved from Data Stream. The sample consists of 372 companies for four consecutive years from 2015 until 2018. Therefore the final sample was 1488 companies-years observation.

\section{Data Collection}

This paper uses secondary data as a source of study. Financial statement data were obtained from Data stream, Thomson Reuters. Besides that, data for hypothesis variables like audit market share, industry specialisation and Big 4 are hand-collected data from the annual report of the total sample 372 companies.

\section{Measurement of Earnings Management}

The dependent variable in this study is earnings management which is determined by discretionary accruals. Discretionary accruals are used as a measurement of earnings management as it is more subtle and hard to be identified by a lay user of financial statements (Abdul Rahman and Mohamed Ali, 2006). ). This measurement method follows the Modified Jones model as proposed by Dechow et al (1995) and Modified Jones Model with ROA as proposed by (Kothari et al., 2005). According to Dechow et al (1995), modified Jones model is better than the original Jones model and the cross-sectional version is improved than the time-series version. Moreover, Kothari et al. (2005) stated that existing discretionary model would be great if corresponding with performance (ROA).

Hence, this study will use these two models to measure the discretionary accruals. Usually, the starting point to measure discretionary accruals is total accruals (Dechow et al., 1995). Then, non-discretionary component is calculated using a particular model, thus allowing total accruals to be sort into discretionary and non-discretionary accruals (Dechow et al., 1995).

\section{Modified Jones Model (Dechow et al, 1995)}

In the modified Jones model, working capital accruals are decomposed into non-discretionary and discretionary accruals (Dechow et al, 1995). The non-discretionary accruals are representing the company's changes in the underlying economic performance that is estimated by managers. Oppositely, discretionary accruals are exposed to managers' 
MANAGEMENT SCIENCES

Vol. 12, No. 1, 2022, E-ISSN: 2225-8329 @ 2022 HRMARS

discretion and therefore are operationalized as a proxy for earnings management in this study (Abdul Rahman and Ali, 2006). Hence, total accruals are comprised of non-discretionary (NDACC) and discretionary accruals (DACC). Hence, the total accruals are:

$$
\text { TACC it }=\text { DACC it }+ \text { NDACC it }
$$

Total accruals (TACC) are determined as the difference between earnings and cash flows from operation (Siregar and Utama, 2008). Earnings (EBEIt) defined as net income before extraordinary items (Siregar and Utama, 2008). Instead, cash flow from operation (CFO) is defined as net cash flows from operating activities stated in the Statement of Cash Flows (Siregar and Utama 2008). As a result, the method proposed by Dechow et al (1995) is as follow:

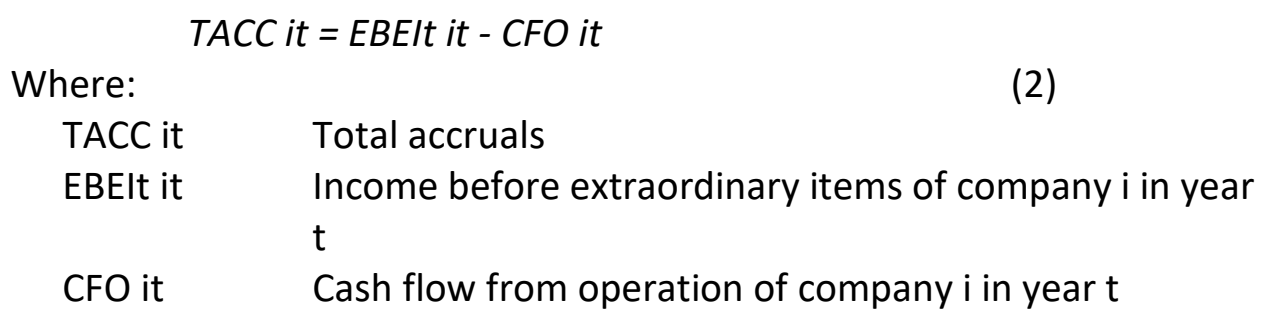

The total accruals calculated in equation (1) are included in the regression model suggested by Dechow et al. (1995) to produce non-discretionary accruals proxy. The nondiscretionary accruals (NDACC) are fitted values in the regression model below and discretionary accruals (DACC) are defined as the residuals or error. Thus, the statistic model by Dechow et al. (1995) is presented below:

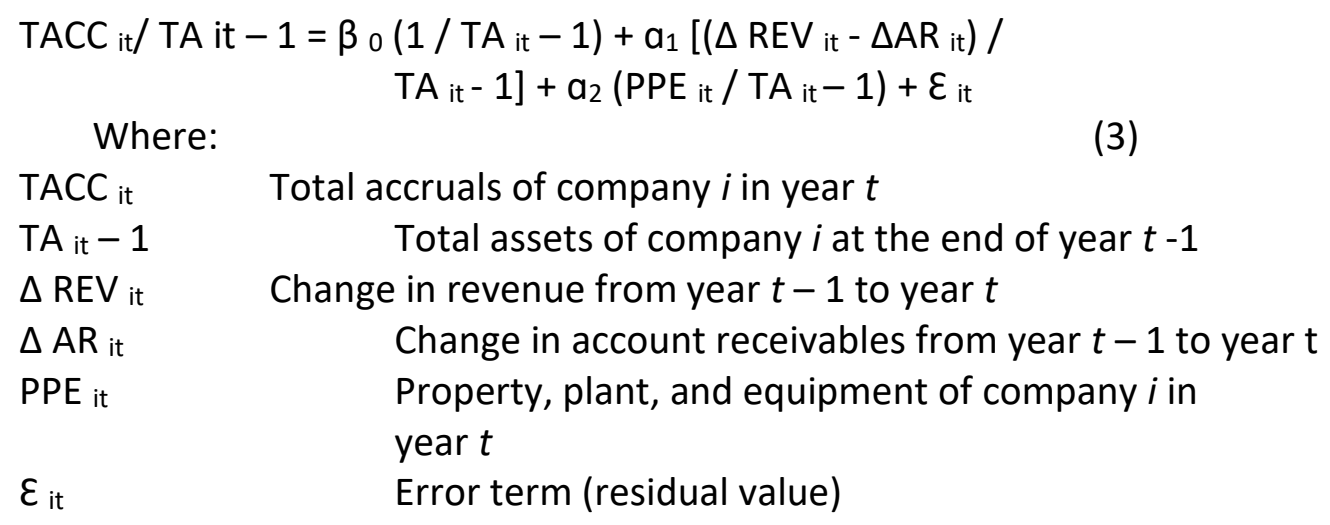

All variables in the regression model are deflated by lagged value total assets to decrease heteroscedasticity problems (Siregar and Utama, 2008; Abdul Rahman and Ali, 2006; Davidson et al., 2004).

\section{Modified Jones Model with ROA (Kothari et al., 2005)}

The second model chosen in this study is based on the Modified Jones Model with Return on Assets (ROA) proposed by Kothari et al (2005). According to Kothari et al. (2005), the accruals of companies that faced uncommon performance are expected to be systematically non-zero. For that reason, company performance is correlated with accruals. Thus, performance matching is vigorous to develop better models of discretionary accruals which are more 
MANAGEMENT SCIENCES

Vol. 12, No. 1, 2022, E-ISSN: 2225-8329 @ 2022 HRMARS

specified to tests earnings management that are immune to the effects of performance (Kothari et al.,2005).

Based on the analysis of discretionary accruals estimation using the traditional Jones model or the Modified Jones model included and adjusted for a performance match, Kothari et al. (2005) found that company's discretionary accruals are quite well-specified. Moreover, Kothari et al. (2005) also recommended that performance matching based on the current year ROA is better instead of matching on the prior year ROA. Subsequently, the performance variable is included in the regression model proposed by Kothari et al. (2005). Accordingly, the formula to calculate total accruals suggested by Kothari et al. (2005) is as follow:

TACC $_{i t}=\left[(\Delta\right.$ non-cash current asset $i t)-\left(\Delta\right.$ current liabilities $_{i t}$ excluding the current portion of long term debt) - (Depreciation and amortization $i t)]$

Total assets it-1.

Where:

$\Delta$ Non-cash current asset it Changes in non-cash current assets in current year of respective company

$\Delta$ Current liabilities it Changes in current liabilities after excluding the portion of long term debt in current year of respective company

Depreciation and amortization it Depreciation and amortization recognized in current year of respective company

Total assets it-1 Total assets for last year of respective company

TACC it Total accruals which consist of discretionary accruals and non discretionary accruals

The total accruals calculated in (4) are then regressed in the following discretionary accruals regression proposed by Kothari et al. (2005):

$$
\begin{gathered}
\text { TACC }_{\text {it }}=a_{0}+a_{1}(1 / \text { ASSETS it }-1)+a_{2}(\Delta \text { SALES it })+a_{3} \text { PPE it }+ \\
a_{4} \text { ROA it }+\varepsilon i t
\end{gathered}
$$

(5)

Where:

ASSETS it - 1 the total assets of company $i$ at the end of year $t-1$

$\triangle$ SALES it sales change in net of the change of account receivable of company $i$ between years $t$ and $t-1$

PPE it the level of gross property, plant, and equipment of company $i$ in year $t$

ROA it ROA of company $i$ at the end of year $t$

$\varepsilon$ it $\quad$ Error term (residual value)

TACC it the total accruals of company $i$ in year

\section{Statistical Analysis}

The Statistical Package for Social Science (SPSS) was used in order to tabulate the data in this study. This study used descriptive and inferential statistic to analyse the data, including t-test correlation analysis and linear regression analysis. Therefore, the following regression was used to test the hypotheses.

DACC it $\quad=\beta_{0}+\beta_{1}\left(\right.$ MSHARE) it $+\beta_{2}$ (AISPE) it $+\beta_{3}\left(\right.$ BIG4) it $+\beta_{4}$ (SIZE) it + $\beta_{5}(\mathrm{ROA})$ it $+\beta_{6}(\mathrm{LEV})$ it $+\varepsilon$ it 
where,

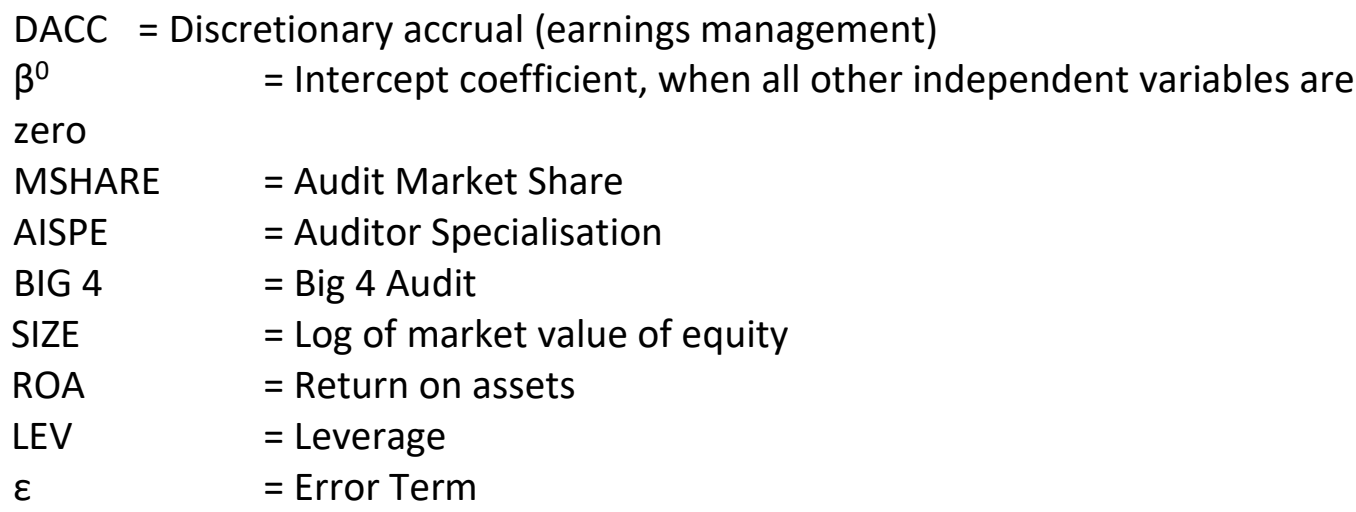

Thus, this study proposed two models to estimate the overall framework.

Modified Jones Model (Dechow et al, 1995)

DACC it $=\beta_{0}+\beta_{1}\left(\right.$ MSHARE) it $+\beta_{2}\left(\right.$ AISPE) it $+\beta_{3}\left(\right.$ BIG4) it $+\beta_{4}$ (SIZE) it $+\beta_{5}$ (ROA) it $+\beta_{6}($ LEV) it $+\varepsilon$ it

and

Kothari et al., 2005

DACC it $=\beta_{0}+\beta_{1}\left(\right.$ MSHARE) it $+\beta_{2}\left(\right.$ AISPE) it $+\beta_{3}\left(\right.$ BIG4) it $+\beta_{4}\left(\right.$ SIZE) it $+\beta_{5}($ ROA $)$ it $+\beta_{6}($ LEV $)$ it + $\varepsilon$ it

\section{Results and Discussion}

\section{Descriptive Analysis}

Table II presents the descriptive statistic for the dependent, independent and control variables of the study. Different approach is used for categorical and continuous data. Categorical data used frequency distribution method while continuous variable applied numerical measure such as minimum, maximum, mean and standard deviation (Pallant, 2005). 
INTERNATIONAL JOURNAL OF ACADEMIC RESEARCH IN ACCOUNTING, FINANCE AND MANAGEMENT SCIENCES

Vol. 12, No. 1, 2022, E-ISSN: 2225-8329 @ 2022 HRMARS

\begin{tabular}{lllll}
\hline $\begin{array}{l}\text { Dependent } \\
\text { Variables }\end{array}$ & Minimum & Maximum & Mean & $\begin{array}{l}\text { Std. } \\
\text { Deviation }\end{array}$ \\
\hline $\begin{array}{l}\text { DACC } \\
\text { (Dechow, 1995) }\end{array}$ & -116.4200 & 124.6527 & 0.0000 & 5.8407 \\
$\begin{array}{l}\text { DACC } \\
\text { (Kothari, 2005) }\end{array}$ & -11.5532 & 11.0695 & 0.0000 & 0.5751
\end{tabular}

\begin{tabular}{|c|c|c|c|c|}
\hline$\frac{\text { Independent }}{\text { Variables }}$ & Minimum & Maximum & Mean & $\begin{array}{l}\text { Std. } \\
\text { Deviation }\end{array}$ \\
\hline \multirow[t]{3}{*}{ MSHARE } & 0.0000 & 28.0500 & 1.8429 & 4.0451 \\
\hline & Frequency & & $(\%)$ & \\
\hline & YES = 1 & $N O=0$ & YES = 1 & $\mathrm{NO}=0$ \\
\hline AISPE & 128 & 1942 & 6.2 & 93.8 \\
\hline BIG4 & 689 & 1381 & 33.3 & 66.7 \\
\hline Control Variables & Minimum & Maximum & Mean & Std. Deviation \\
\hline SIZE & 0.0000 & 7.5600 & 3.2404 & 2.4271 \\
\hline ROA & -2.1171 & 3.7400 & 0.0896 & 0.9895 \\
\hline LEV & 0.0199 & 0.7410 & 0.1824 & 0.1600 \\
\hline
\end{tabular}

Note: The sample consists of 1488 companies-year observations for the period 2011 until 2014 equivalent to 372 public listed companies in Malaysia. DACC is discretionary accruals calculated using Modified Jones Model as recommended by (Dechow et al., 1995; Kothari et al., 2005). MSHARE is audit market share that measured by amount of audit fee. AISPE is audit industry specialization that determined by identifying audit companies that have $10 \%$ or more of market share in any particular industry. BIG4 is dummy variable equal to 1 if companies audited by Big 4 and 0 if companies audited by non-Big4 auditor. SIZE is natural logarithm of market capitalization. ROA is return on assets measured using operating income or earnings before interest and tax (EBIT) divide by total assets. LEV is leverage calculated by divide total debt with total assets.

Based on the table, the minimum value of DACC measured using model proposed by Dechow et al (1995) is -116.4200 and maximum value is 124.6527 . The minimum and maximum value of DACC calculated using model proposed by Kothari et al (2005) is 11.5532 and 11.0695 respectively. The mean value of DACC for both models is 0.0000 . For Audit Market Share, the minimum is 0.0000 and the maximum is 28.0500 . For Audit Specialisation, $6.2 \%$ listed company have meet the threshold of $10 \%$ or more of audit market share. In terms of companies audited by Big 4 represent by BIG4, 33.3\% of the sample is audited by Big 4 audit companies. Additionally, the range value of SIZE is between the ranges of 0.0000 to 7.5600 while the mean is 3.2404 . For ROA, the range value is -2.1171 to 3.7400 whereas the mean value is 0.0896 . Furthermore, the minimum and maximum value for leverage is 0.0199 and 0.7410 respectively. The mean value of leverage is 0.1824 .

\section{Correlation Analysis}

Correlation analysis is a measure of strength of the linear association between two variables. The purpose is to illustrate the strength of the linear relationship which exists between the 
MANAGEMENT SCIENCES

Vol. 12, No. 1, 2022, E-ISSN: 2225-8329 @ 2022 HRMARS

two numerical variables instead of seeking to predict one variable with another variable. This study use Pearson's rank correlation to measure the direction, strength and significant relationship between dependent, independent and control variables. The sign of the correlation indicates either positive or negative direction between the two variables (Pallant, 2005). According to Cohen (1988), if the value is between ranges 0.1 to 0.29 , the correlation between the variables is weak. Furthermore, the medium correlation value is between range of 0.3 to 0.49 and the value above 0.5 consider as strong correlation.

Thus, correlation analysis has been conducted to determine the relationship between dependent variables proxy by discretionary accrual measured using model proposed by Dechow et al (1995); Kothari et al (2005) with independent variables comprise audit market share, industry specialisation and Big 4. Furthermore, the control variables are also included in the correlation analysis which consists of continuous variables. Multicollinearity can be detected in the correlation analysis. Multicollinearity is the situation where two or more variables are highly correlated. The variables suffer multicollinearity problem if the relationship between the variables is more than 0.9 levels (Pallant, 2005). If this problem occurs, one of the variables must be omitted from the regression. In this study, no multicollinearity exists since no variables are found to be highly correlated for more than 0.9 . Based on table III, the correlation result illustrates that most of the variables have significant relationship. The highest correlation is between switching audit market share (MSHARE) and industry specialisation (AISPE) at 0.797. The correlation value is higher than 0.5 and it shows that there is a strong and negative correlation between the two variables. Additionally, the relationship between MSHARE and AISPE has significant relationship at 0.01. In term of other control variables, BIG4 indicated positive significance at $1 \%$ to MSHARE and AISPE, positive relationship to DACC (Dechow et al., 1995) and negative relationship to DACC (Kothari et al., 2005).

In a meantime, company size (SIZE) has significantly positive relationship with the MSHARE, AISPE AND BIG4 at 0.01. Return on Equity (ROA) also has significantly positive relationship at $1 \%$ with the MSHARE, BIG4 and SIZE. The smallest correlation is correlation between ROA and LEV at -0.047 . The relation of ROA and leverage (LEV) has negative relationship at $5 \%$ which indicated that weak correlation between these two variables. 
MANAGEMENT SCIENCES

Vol. 12, No. 1, 2022, E-ISSN: 2225-8329 @ 2022 HRMARS

Table III: Correlation Matrix of Earnings Managements Determinants Variables

\begin{tabular}{lllllllll}
\multicolumn{1}{c}{$\begin{array}{l}\text { DACC } \\
\text { (Decho } \\
\text { w) }\end{array}$} & $\begin{array}{l}\text { DACC } \\
\text { (Kothar RE }\end{array}$ & MSHA & AIS & BIG & SIZ & RO & LEV \\
DACC & & & & & & A & \\
(Kothar & -.023 & & & & & & \\
i et al., & & & & & & & \\
2005) & & & & & & & \\
MSHAR & .023 & .003. & & & & & \\
E & .023 & .004 & $.797^{* *}$ & & & & \\
AISPE & .004 & -.001 & $.571^{* *}$ & 304 & & & \\
BIG4 & .042 & -.001 & $.197^{* *}$ & $* *$ & .24 & & \\
SIZE & .017 & .000 & $.068^{* *}$ & .12 & $3^{* *}$ & .11 & \\
ROA & -.001 & -.009 & -.020 & $2 * *$ & .15 & $1 * *$ & - \\
LEV & & & & .03 & $0 * *$ & .02 & .04 \\
& & & & 4 & - & 2 & $7^{*}$ \\
& & & & - & .02 & & \\
& & & & .04 & 0 & &
\end{tabular}

Notes: * and ${ }^{* *}$ represents significance at 0.05 and 0.01 levels. (1) is DACC (Dechow et al., 1995) calculated using Modified Jones Model as recommended by Dechow et al. (1995). DACC (Kothari et al., 2005) is measured using Modified Jones with ROA as proposed by Kothari et al. (2005). MSHARE is audit market share that measured by amount of audit fee. AISPE is audit industry specialization that determined by identifying audit companies that have $10 \%$ or more of market share in any particular industry. BIG4 is dummy variable equal to 1 if companies audited by Big 4 and 0 if companies audited by non-Big4 auditor. SIZE is natural logarithm of market capitalization. ROA is return on assets measured by operating income or earnings before interest and tax (EBIT) divide by total assets. LEV is leverage calculated by divide total debt with total assets.

\section{Normality Test}

Normality can be assessed by obtaining skewness and kurtosis values (Pallant, 2005). Skewness is the value of that provides an indication of the symmetry of the distribution. Besides, Kurtosis provides information regarding the peakedness of the distribution (Pallant, 2005). The data is significantly non-normally distributed if the skewness is distributed outside the range of \pm 1.96 and kurtosis outside the range of \pm 2.0 . Van der Waerden method used to resolve the non-normal data. Van der Waerden's formula is used to recover the percentiles by computing quantiles according to the rank of given score value relative to the sample size (Solomon and Sawilowsky, 2009). Yet, this transform technique only can be applied for continuous variables. 
MANAGEMENT SCIENCES

Vol. 12 , No. 1, 2022, E-ISSN: 2225-8329 (C) 2022 HRMARS

Table IV: Results for Normality Test

\begin{tabular}{|l|l|l|}
\hline & Skewness & Kurtosis \\
\hline DACC (Dechow et al., 1995) & 0.002 & -.0 .039 \\
\hline DACC (Kothari et al., 2005) & 0.000 & -0.058 \\
\hline MSHARE & 1.266 & 0.504 \\
\hline SIZE & -0.542 & -1.546 \\
\hline ROA & 0.007 & -0.024 \\
\hline LEV & 0.080 & -0.034 \\
\hline
\end{tabular}

Note: The sample consists of 1488 companies-year observations for the period 2011 until 2014 equivalent to 372 public listed companies in Malaysia. DACC is discretionary accruals calculated using Modified Jones Model as recommended by Dechow et al. (1995) and Kothari et al. (2005). MSHARE is audit market share that measured by amount of audit fee. SIZE is natural logarithm of market capitalization. ROA is return on assets measured using operating income or earnings before interest and tax (EBIT) divide by total assets. LEV is leverage calculated by divide total debt with total assets.

These transform method were applied for all the variables that suffer normality problems which were shown by the value of skewness outside the acceptable range of \pm 1.96 and kurtosis outside the range of \pm 2.0 include DACC (Dechow et al., 1995), DACC (Kothari et al., 2005), MSHARE and LEV. However, this transform method was not applied for the SIZE and ROA since its show the value of skewness and kurtosis within the range of \pm 1.96 and \pm 2.0 respectively. Table 4.3 shows the analysis of skewness of DACC (Kothari et al., 2005) indicates perfectly normal.

\section{Multiple Regression Analysis Kothari et al., 2005}

As illustrated in Table $\mathrm{V}$, the result shows the explanatory power of the model as measured by the R Square and adjusted R Square. However, adjusted R Square is a better indication to examine how well the model fit the data plot. As reported, the value of adjusted $R$ Square is $5.7 \%$ which indicates the possibility of earnings manipulation practices of an organization that can be explained by the model. Multiple regressions can also collect data on problems with multicollinearity that might not appear in the correlation matrix. The result showed in the Tolerance and Variance inflation factor (VIF). As specified in table 4.4, the Tolerance value of all variables is more than 0.10 and VIF value is less than 10 . Hence, these indicated that all the variables are free from multicollinearity problem. Besides, table 4.4 shows unstandardized beta Coefficients and SIZE contributes high coefficient of -0.094 . The Beta value for ROA was slightly lower (-0.062) indicating that it made less contribution and followed by LEV $(-0.025)$. 
MANAGEMENT SCIENCES

Vol. 12, No. 1, 2022, E-ISSN: 2225-8329 ๔ 2022 HRMARS

Table V: Multiple Regressions for Kothari et al., 2005

\begin{tabular}{lllll}
\hline Model & Beta Coefficient & t-stats & Tolerance & VIF \\
\hline Intercept & & $3.929^{* *}$ & & \\
MSHARE & 0.034 & 0.658 & 0.443 & 2.784 \\
AISPE & 0.016 & 0.547 & 0.641 & 1.375 \\
BIG4 & -0.076 & $-1.754^{*}$ & 0.682 & 1.466 \\
SIZE & -0.094 & $-4.120^{* *}$ & 0.662 & 1.510 \\
ROA & -0.062 & $-2.786^{* *}$ & 0.725 & 1.379 \\
LEV & -0.025 & -1.162 & 0.861 & 1.161 \\
Adj. R - Square & $5.7 \%$ & & & \\
N & 1488 & & &
\end{tabular}

Notes: ${ }^{*}$ and ${ }^{* *}$ symbolizes statistical significance at 0.10 and 0.01 levels respectively. DACC is normal score of discretionary accruals calculated using Van der Waerden formula. DACC is measured using Kothari et al. (2005). MSHARE is normal score of audit market share that measured by amount of audit fee using Van der Waerden formula. AISPE is audit industry specialization that determined by identifying audit companies that have $10 \%$ or more of market share in any particular industry. BIG4 is dummy variable equal to 1 if companies audited by Big 4 and 0 if companies audited by non-Big4 auditor. SIZE is natural logarithm of market capitalization. ROA is return on assets measured using operating income or earnings before interest and tax (EBIT) divide by total assets. LEV is is normal score of leverage calculated by divide total debt with total assets using Van der Waerden formula

Hypothesis 1: There is a significant relationship between audit market share and earnings management

The first hypothesis is whether audit market share has significant impact on earnings management. Table 4.4 shows that positive coefficient value of audit market share (MSHARE) at 0.034 and $t-$ value are at 0.658 . It indicates that there is no significant relationship between audit market share and earnings management. This result is consistent with the study of Feng and Fei (2002) (2002) which has taken China companies as the sample. Thus, first hypothesis is not supported.

\section{Hypothesis 2: There is a Significant Relationship between Industry Specialization and earniNGS MANAGEMENT}

The second hypothesis is whether there is significant relationship between industry specialisation and earnings management. The result in table 4.4 also found that industry specialisation have positive coefficient value and no significant relationship (coefficient $=0.016$ and $t$-value $=0.547$ ) with earnings management. It is supported by Balsam et al. (2003) and Reichelt and Wang (2010). In short, the second hypothesis is not supported.

\section{Hypothesis 3: There is a Significant Relationship between Big 4 and Earnings Management}

The third hypothesis is whether Big 4 has significant impact on earnings management. Table 4.4 shows that coefficient value of BIG4 is -0.076 and $t$ - value are at -1.754 which is achieved the significant level at $10 \%$. Thus, it indicates that there is a significant relationship between Big 4 and earnings management. The negative sign indicates the negative significant impact 
MANAGEMENT SCIENCES

Vol. 12, No. 1, 2022, E-ISSN: 2225-8329 @ 2022 HRMARS

of Big 4 towards earnings management. This means that the presence of Big 4 could reduce the occurrence of earnings management in the companies. Therefore, hypothesis 3 is supported by the result which used Kothari et al. (2005) in measuring discretionary accruals as proxy of earnings management. This result is consistent with the study conducted by Becker, Defond, Jiambalvo and Subramanyam (1998) and Chia, Lapsley and Lee (2007) which found that Big 6 audit companies significantly reduce earnings management activities. This result provides underlying rational that large auditors are more skilled and provide higher quality service rather than smaller auditors as large auditors lose more when audit failure occurs. Therefore, they have harder incentives to predict the likelihood of audit failure in order to maintain their good reputation (Lee and Lee, 2013; Bauwhede et al., 2003).

\section{Modified Jones Model (Dechow et al., 1995)}

Table VI illustrates the result for the second model in measuring the discretionary accruals which used Modified Jones Model as proposed by Dechow et al. (1995). In the multiple regression tables, it shows that the details of the tolerance values of all variables are more than 0.01 and the VIF values is less than 10. Therefore, the entire variables do not violate the multicollinearity assumption. For this result, $\mathrm{R}$ Square value is $4.8 \%$ which means that the audit market share, industry specialization, BIG4, SIZE, ROA, and LEV explained 4.8 percent of the variance of discretionary accruals.

Table VI: Multiple Regressions for Modified JonesModel (Dechow et al., 1995)

\begin{tabular}{lllll}
\hline Model & Beta Coefficient & t-stats & Tolerance & VIF \\
\hline Intercept & & $-2.620^{* *}$ & & \\
MSHARE & -0.040 & -0.767 & 0.443 & 2.784 \\
AISPE & -0.014 & -0.467 & 0.641 & 1.375 \\
BIG4 & 0.002 & 0.055 & 0.682 & 1.466 \\
SIZE & 0.039 & $4.198^{* *}$ & 0.662 & 1.510 \\
ROA & 0.013 & 0.583 & 0.725 & 1.379 \\
LEV & -0.004 & -0.017 & 0.861 & 1.161 \\
Adj. R - Square & $3.7 \%$ & & & \\
N & 1488 & & & \\
\hline
\end{tabular}

Notes: ${ }^{*}$ and ${ }^{* *}$ symbolizes statistical significance at 0.10 and 0.01 levels respectively. DACC is normal score of discretionary accruals calculated using Van der Waerden formula. DACC is measured using Modified Jones Model as recommended by Dechow et al. (1995). MSHARE is normal score of audit market share that measured by amount of audit fee using Van der Waerden formula. AISPE is audit industry specialization that determined by identifying audit companies that have $10 \%$ or more of market share in any particular industry. BIG4 is dummy variable equal to 1 if companies audited by Big 4 and 0 if companies audited by non-Big 4 auditor. SIZE is natural logarithm of market capitalization. ROA is return on assets measured using operating income or earnings before interest and tax (EBIT) divide by total assets. LEV is is normal score of leverage calculated by divide total debt with total assets using Van der Waerden formula.

Hypothesis 1: There is a Significant Relationship between Audit Market Share and Earnings Management 
MANAGEMENT SCIENCES

Vol. 12, No. 1, 2022, E-ISSN: 2225-8329 @ 2022 HRMARS

The first hypothesis is whether audit market share have significant relationship toward earnings management. Table 4.5 demonstrates that there is no significant relationship between audit market share and earnings management. Therefore, hypothesis 1 is not supported by the result which used the Modified Jones Model as proposed by Dechow et al. (1995) in measuring discretionary accruals as proxy of earnings management.

\section{Hypothesis 2: There is a Significant Relationship between Industry Specialization and Earnings Management}

The second hypothesis is whether industry specialisation has significant relationship toward earnings management. Table 4.5 demonstrates that there is no significant relationship between industry specialisation and earnings management. Therefore, hypothesis 2 is rejected by the result which used the Modified Jones Model as proposed by Dechow et al. (1995) in measuring discretionary accruals as proxy of earnings management.

\section{Hypothesis 3: There is a Significant Relationship between Big 4 and Earnings Management}

The third hypothesis is whether Big 4 have significant relationship toward earnings management. Table 4.5 demonstrates that there is no significant relationship between Big 4 and earnings management. Therefore, hypothesis 3 is not supported by the result which used the Modified Jones Model as proposed by Dechow et al. (1995) in measuring discretionary accruals as proxy of earnings management. This result is consistent with Ishak, et al. (2011) which found that Big 4 does not affect the discretionary accruals.

\section{Conclusion}

This study found a significant negative relationship between Big 4 towards earnings management. It explained that the large of audit size, the lower the occurrence of earnings management. In conjunction of the findings, it might be said that this proxy of audit quality could be the determinant to influence the likelihood of earnings management in Public Listed companies in Malaysia. Despite numerous studies pertaining to the earnings management issues, the relationship between earnings management and of audit market share, industry specialisation and Big 4 especially in developing country such as Malaysia are still scarce. Therefore, this study provides some contribution to the body of knowledge related on the earnings management in Malaysian environment.

Moreover, the findings of this study will provide a significant contribution to public listed companies' users such as investors, management team, public, financial institution and other stakeholders. The findings will provide information pertaining to the incentives and elements that contribute to the earnings management occurrence. Besides that, this study also provides extensive overview to the standard setter to tighten the rules and regulations in financial reporting so as to restore public assurance on the reliability of the financial information provided by corporations. In the meantime, the information from this study could generate awareness among users of financial reporting concerning the nature of financial disclosure and socioeconomics in Malaysia.

However, this study is also subjected to several limitations. Firstly, this study used a sample of 372 companies with three years period which is considered as small data as compared to the previous study that used the sample of at least 10 years period. Secondly, the study covers only seven industries of public listed companies in Bursa Malaysia which has been excluded the financial institution which cannot be generalized for the financial institution. Thirdly, 
MANAGEMENT SCIENCES

Vol. 12, No. 1, 2022, E-ISSN: 2225-8329 @ 2022 HRMARS

insufficient data obtained from the Datastream. The row data is found to be incomplete when some values of certain figure are needed as certain companies did not disclose such as Selling General and Administrative Expenses, and Total Debt. Thus, some companies need to be excluded from this study that might affect the result. Lastly, the study used only two accruals model which are Modified Jones Model as proposed by Dechow et al (1995) and model suggested by Kothari et al (2005). The possibility to develop more significant findings could be higher if the study used more different models in calculating the discretionary accruals.

Future studies can be extended to explore the issues regarding earnings management. Alternatively, the study can be conducted by utilizing survey, questionnaire, or interview to collect data regarding the perception of users of financial statement, regulator and managers on earnings management. Besides, future research could explore the harmful and beneficial magnitude of earnings management towards the stakeholders. Moreover, in future, the research could also extend by increasing the sample size and time frame as it might be able to provide significant results and more generally applicable for various conditions. Furthermore, future study could use the most recent earnings management detection mode to obtain more accurate measurement for earnings management as different model is applicable for certain economic situation.

\section{Acknowledgement}

Authors would like to thank ARI HICOE and Malaysian Ministry of Higher Education for the support.

\section{References}

Rahman, R. A., \& Ali, F. H. M. (2006). Board, audit committee, culture and earnings management: Malaysian evidence. Managerial Auditing Journal.

Balsam, S., Krishnan, J., \& Yang, J. S. (2003). Auditor industry specialization and earnings quality. Auditing: A journal of practice \& Theory, 22(2), 71-97.

Bauwhede, V. H., Willekens, M., \& Gaeremynck, A. (2003). Audit firm size, public ownership, and firms' discretionary accruals management. ThelinternationalJjournal of Accounting, 38(1), 1-22.

Becker, C. L., DeFond, M. L., Jiambalvo, J., \& Subramanyam, K. R. (1998). The effect of audit quality on earnings management. Contemporary Accounting Research, 15(1), 1-24.

Bonner, S. E., \& Lewis, B. L. (1990). Determinants of auditor expertise. Journal of Accounting Research, 28, 1-20.

Cahan, S. F., Godfrey, J. M., Hamilton, J., \& Jeter, D. C. (2008). Auditor specialization, auditor dominance, and audit fees: The role of investment opportunities. The Accounting Review, 83(6), 1393-1423.

Chia, Y., Lapsley, I., and Lee, H.-W. (2007). Choice of auditors and earnings management during the Asian financial crisis. Managerial Auditing Journal, 22 (2), 177-196.

Chih, H.-L., Shen, C.-H., and Kang, F.-C. (2008). Corporate Social Responsibility, Investor Protection, and Earnings Management: Some International Evidence. Journal of Business Ethics, 79, 179-198.

Choi, J. H., Kim, C., Kim, J. B., \& Zang, Y. (2010). Audit office size, audit quality, and audit pricing. Auditing: A Journal of Practice \& Theory, 29(1), 73-97.

Cohen, J. (1988). Statistical Power Analysis for the Behavioral Sciences; 2nd Edition. New Jersy: Lawrence Erlbaum Associates Inc. 
MANAGEMENT SCIENCES

Vol. 12, No. 1, 2022, E-ISSN: 2225-8329 ๔ 2022 HRMARS

Craswell, A. T., \& Taylor, S. L. (1991). The market structure of auditing in Australia: The role of industry specialization. Research in Accounting Regulation, 5(1), 55-77.

DeAngelo, L. (1981). Auditor Size And Audit Quality. Journal of Accounting and Economics 3, 183-199.

Dechow, P., Sloan, R., and Sweeney, A. (1995). Detecting Earnings Management. The Accounting Review, 70(2), 193-225.

Dechow, P. M., and Sloan, R. G. (1991). Executive incentives and the horizon problem: An empirical investigation. Journal of Accounting and Economics, 14, 51-89.

DeFond, M. L., Francis, J. R., \& Wong, T. J. (2000). Auditor industry specialization and market segmentation: Evidence from Hong Kong. Auditing: A Journal of Practice \& Theory, 19(1), 49-66.

Feng, L., \& Fei, X. (2002). Risk based auditing, litigation risk and auditing quality [J]. Accounting Research, 2.

Healy, P. (1985). The impact of bonus schemes on the selection of accounting principles. Journal of Accounting and Economics, 7, 85-107.

Healy, P., and Wahlen, J. (1999). A Review of the Earnings Management Literature and Its Implications for Standard Setting. Accouning Horizons, 13(4), 365-383.

Inaam, Z., Khmoussi, H. L. I. O. U. I., \& Fatma, Z. (2012). Audit quality and earnings management in the Tunisian context. International Journal of Accounting and Financial Reporting, 2(2), 17.

Jensen, M., and Meckling, W. (1976). Theory of the Companies: Managerial Behavior , Agency Costs and Ownership Structure. Journal of Financial Economics, 3(4), 305-360.

Jeong, S. W., \& Rho, J. (2004). Big Six auditors and audit quality: The Korean evidence. The International Journal of Accounting, 39(2), 175-196.

Keefe, T. B., King, R. D., \& Gaver, K. M. (1994). Audit fees, industry specialization, and compliance with GAAS reporting standards. Auditing, 13(2), 41.

Knechel, W. R., Krishnan, G. V., Pevzner, M., Shefchik, L. B., \& Velury, U. K. (2013). Audit quality: Insights from the academic literature. Auditing: A Journal of Practice \& Theory, 32(Supplement 1), 385-421.

Kothari, S., Leone, A., and Wasley, C. (2005). Performance Matched Discretionary Accrual Measures. Journal of Accounting and Economics, 39(1), 163-197.

Krishnan, G. V. (2003). Does Big 6 auditor industry expertise constrain earnings management?. Accounting Horizons, 17, 1-16.

Lee, H. L., \& Lee, H. (2013). Do Big 4 audit firms improve the value relevance of earnings and equity?. Managerial Auditing Journal.

Mansor, N., \& Maruhun, E. N. S. (2013). Audit market concentration and auditor's industry specialization. Procedia-Social and Behavioral Sciences, 91, 48-56.

Mayangsari, S., \& Sudibyo, B. (2006). An empirical analysis of auditor litigation. The Indonesian Journal of Accounting Research, 9(1).

Owhoso, V. E., Messier, Jr, W. F., \& Lynch, Jr, J. G. (2002). Error detection by industryspecialized teams during sequential audit review. Journal of accounting research, 40(3), 883-900.

Reichelt, K. J., \& Wang, D. (2010). National and office-specific measures of auditor industry expertise and effects on audit quality. Journal of Accounting Research, 48(3), 647-686.

Rhode, J. G., Whitsell, G. M., \& Kelsey, R. L. (1974). An analysis of client-industry concentrations for large public accounting firms. The Accounting Review, 49(4), 772787. 
Saleh, N. M., Iskandar, T. M., \& Rahmat, M. M. (2003, October). Management intention to avoid losses and earnings decreases: Evidence from Malaysia. In Proceeding of International Seminar on Sustainable Economic and Business Development in An Era of Globalization, Universiti Kebangsaan Malaysia, Universitas Syiah Kuala and Universitas Bengkulu (pp. 13-14).

Scott, W. (2011). Financial Accounting Theory. 6th edition (Prentice Hall).

Schipper, K. (1989). Earnings management. Accounting Horizon, 3(4), 91.

Siregar, S. V., \& Utama, S. (2008). Type of earnings management and the effect of ownership structure, firm size, and corporate-governance practices: Evidence from Indonesia. The International Journal of Accounting, 43(1), 1-27.

Sulaiman, M., \& Govindan, K. (2000, June). Macroeconomic fundamentals of the Malaysian economy: before and after the crisis. In National Seminar on Strengthening the Macroeconomic Fundamentals of the Malaysian Economy, organized by UUM and UKM, June (p. 5).

Sun, J., \& Liu, G. (2013). Auditor industry specialization, board governance, and earnings management. Managerial Auditing Journal.

Tangjitprom, N. (2013). The Role of Corporate Governance in Reducing the Negative Effect of Earnings Management. International Journal of Economics and Finance, 5(3) , 213-220.

Tariverdi, Y., Moradzadehfard, M., \& Rostami, M. (2012). The effect of earnings management on the quality of financial reporting. African Journal of Business Management, 6(12), 4603-4611.

Zakaria, N. B., and Daud, D. (2013). Does Big 4 Affect the Earnings Response Coefficient? Evidence From Malaysia. Journal of Modern Accounting and Auditing, 9(9), 1204-1215. 